PUBLISHED AS:

"How Unstable? Volatility and the Genuinely New Parties in Eastern Europe," European Journal of Political Research, 44(1): 391-412, 2005 


\title{
HOW UNSTABLE? VOLATILITY AND THE GENUINELY NEW PARTIES IN EASTERN EUROPE
}

\begin{abstract}
Measuring of party system stability in Eastern Europe during the first decade of democratic elections presents problems. The traditional quantitative measure - volatility does not distinguish between the dynamics among incumbent parties and the rise of genuinely new ones. I propose a new additional measure - success of genuinely new parties - and compare it to volatility. The subsequent performance of initially successful genuinely new parties is analysed. While volatility has been remarkably high in East European countries, the genuinely new parties have in general not been very successful. Instability of party systems in the region stems rather from the inner dynamics of already incumbent actors than from the rise of new contenders.
\end{abstract}

How long does it take in newly established democracies to develop reasonably stable party systems? More specifically, do party systems in East Central Europe show signs of stabilization? The answer to this question depends on using adequate indices. In addition to the traditional volatility of votes, this study focuses on the success of genuinely new parties, those that are not offshoots of existing parties or creations of already well-known politicians.

Aggregate volatility [1] has long been the standard indicator used for measuring party system stability. It has been utilized to assess change or persistence in Western Europe (e.g., Pedersen 1979; Bartolini \& Mair 1989; Crewe \& Denver 1985; Ersson \& Lane 1998), and also for emerging multiparty systems of postcommunist countries (Korasteleva 2000; Krupavičius 1999; Mainwaring 1998; Rose et al. 1998; Tóka 1997). Volatility has led to almost universal conclusion that the level of instability in those new democracies is significantly higher than in Western Europe. Yet, high levels of volatility contradict authors who emphasize consolidating and stabilizing tendencies in Eastern European party systems (e.g., Olson 1993; Ágh 1998; Chan 2001). 
This article proposes an additional measure of instability - the performance of genuinely new parties. It takes into account the specific traits of post-communist party systems, especially the claimed cartelisation (see Szczerbiak 2001, Klíma 1998, based on Katz \& Mair 1995), where the major players of party political scene remain remarkably intact despite high levels of voter volatility.

The article starts with an in-depth analysis of volatility levels in post-communist countries from 1990 to 2000 that will later be used for comparison with the level of support for genuinely new parties. Also, the later performance of initially successful parties (those gaining representation) will be assessed. [2]

The countries studied include all nine countries west of pre-1940 Soviet Union and north of Yugoslavia - Bulgaria, the Czech Republic, Estonia, Hungary, Latvia, Lithuania, Poland, Romania, the Slovak Republic - plus Slovenia. These countries are widely assumed to be on the forefront of democratisation in the region: they have relatively well developed democratic institutions, hold fairly free and competitive elections, and have had mostly successful transitions to relatively stable market economy. The time frame of the study is the first decade of democratic politics in the region, from 1990 to 2000.

\section{HOW TO MEASURE VOLATILITY?}

In principle, volatility is an index that reflects the extent of personal vote transfers between subsequent elections. As data on individual voter level are normally not available, electoral statistics are used to provide a cue to that. Even though there are counterexamples where the correlation between personal and overall is poor, the index of volatility nevertheless approximates the level of individual vote shifts well (Bartolini \& Mair 1990: 20-34). Attempts to use the index for the emerging post-communist democracies have been based on the assumption that ' $\mathrm{t}]$ he index of volatility is not only a good indicator to observe voter switches from one party to another in subsequent elections, but it is an indicator of relative strength and 
social rooting of leading parties as well' (Krupavičius 1999: 8). Accordingly, it has been argued that volatility is the single most important indicator of presence or absence of party system stabilization (Tóka 1997: 3).

Unquestionably there is connection between the level of volatility in a country and the stability of its party system. At the same time, it is doubtful whether the index is sufficient to draw far-reaching conclusions about the stability of a party system, especially in the Eastern European context where volatility is relatively high. Below, perhaps the most problematic technical issue of dealing with splits and mergers is discussed. A thorough account of various other issues has been provided by Rattinger (1997), several of these only become more acute in postcommunist countries compared to western democracies.

Three main approaches to calculating volatility index could be used in the case of splits and mergers. First, the split or merged parties could be considered as one in the election where they ran separately - thus calculating the volatility score between the vote share they received together and their summed vote shares on the election contested separately. Second, the basis of calculation could be the largest of parties when being separate - the basis for calculation thus being its vote share when running separately against the vote share when running together. In this case, the votes for the small(er) partner(s) are considered to be cast for a new party and hence volatility score is higher than in the first case. Third, merged or split parties could be completely detached from their predecessors or successors. In this case all the votes given to these are considered to go to new parties and volatility score is even higher.

Clearly, all three approaches have important shortcomings. The first might be argued to underestimate voter mobility and thus level of volatility as it assumes that the voters of the split/merged parties should 'naturally' also support the joint party. It fails to see the latter as an entity by itself - also minimizing the number of individual volatility scores. It has been argued that there is a positive relationship between the number of parties and the level of volatility (Pedersen 
1979: 378, 386), and such pooling of parties thus decreases the index. The second approach ignores the possibility that the supporters of predecessor or successor parties themselves might not consider their vote floating at all when voting for the joint party. This is especially the case with loose and/or temporary electoral coalitions that have been relatively frequent in Eastern Europe. Sometimes the voters might not even be clearly aware that they are supporting something else than on preceding election given the relatively candidate-centred nature of electoral politics in Eastern Europe. The third approach is most sensitive to the changes of electoral landscape and would provide the highest volatility scores. At the same time it clearly fails to reflect important continuation between the past and present parties. Similar approaches could be used in the case of merger, where the continuation will be under the name of one of the parties involved or a split where one of the successors retains the name of the predecessor party. More apparent continuation of identity under such circumstances strengthens the case for the second approach. At the same time it will be concentrating perhaps too much attention on the party labels.

In this article the first approach is used, as it seems to balance better between shortcomings and merits. Clearly, the third approach is likely to produce excessive volatility scores. The main advantages of the first over the second approach are the following:

1) It is more appropriate in cases where splits or mergers have occurred by pooling the vote shares of the relevant parties on both elections.

2) The index of aggregate volatility should be foremost a reflection of the sum of individual vote changes. In the case of splits and mergers the voters who support both the constituent parts and the joint party/electoral coalition are more likely to perceive themselves as vote-retainers than vote-changers. When a voter for a minor partner in a merger knowingly tries to keep his/her earlier preference, he or she has only the possibility to support the joint party. Hence such vote transfers should not add to volatility. Similarly, in the case of split, those supporters of the 
joint party who do not want to change choose among the successors. It is especially so in the case of (loose) electoral coalitions splitting up where the voters might easily be supporting actually the same party that is still not clearly reflected in the electoral statistics. In short, in a situation where the faithful have no other place to go, their seeming vote transitions should not increase overall volatility.

3) The second approach might be appropriate when dealing with splits and mergers having a clearly identifiable major partner (i.e., dealing with lesser offshoots and incorporations of minor parties). Some, if not most, splits and mergers in post-communist countries have been more complex, including two or several more or less equal partners, so that identifying a single major partner is often complicated. Also, the splits and mergers might sometimes be of a tactical rather than substantive nature. For instance, parties may form an electoral coalition just to be sure to surpass the electoral threshold, or run separately to attract more voters while sitting happily on the government or opposition benches together.

4) Most attempts to measure volatility in traditional democracies have been closest to the first approach (e.g., Bartolini \& Mair 1990). Thus, so as to allow comparisons between West and East European volatility scores it is advisable to use the first approach.

It should also borne in mind that for any volatility scores to be meaningful, their calculation should be based on data of good quality. Fortunately, sufficiently reliable electoral results are easily available in print (Rose et al. 1998) and over Internet for post-communist countries. Moreover, the evolution of individual parties must be mapped carefully. It is a thankless task when studying the Eastern European post-communist countries as the parties are numerous and their name changes, splits and mergers, are frequent. If a relatively popular party that is in fact a continuation of a previous one is counted as new, it can inflate the volatility levels misleadingly. For tracing the evolutionary paths of the parties, I have used 
mostly Rose et al. (1998), complemented by encyclopaedias of the world and East European parties (Day et al. 1996, Szajkowski 1994) and various reliable Internet sources.

\section{VOLATILITY IN POST-COMMUNIST COUNTRIES}

The relatively high level of electoral volatility in East European post-communist countries as compared to Western Europe has been often reported (Rose et al 1998: 118-119, for the volatility scores of elections in ten Eastern European countries from 1991-2000 see Table 1.). [3] According to Bartolini and Mair (1990), the West European average volatility between 1885 and 1985 was 8.6 per cent, but increased significantly in the 1990s to an average 12.6 per cent (Mair 2002: 131). Even the latter is two times lower than the average for the elections under study here in Eastern Europe. None of these elections score below the West European average of principally the same period. At the same time there is remarkable variation in East European volatility levels. While Lithuania and Latvia have witnessed extreme volatility populating the bottom of Table 1 (with respective country averages being as high as 42.2 and 40.9 per cent), volatility in countries like Slovakia and Bulgaria has not been significantly higher than in the Western Europe during the same period (with averages respectively at 18.4 and 20.7 per cent). 
Table 1. Volatility for 25 Eastern European elections

\begin{tabular}{|c|c|}
\hline & volatility \\
\hline $\begin{array}{ll}\text { Slovakia } 1994 \\
\end{array}$ & $\overline{13.6}$ \\
\hline Romania 1996 & $\overline{14.3}$ \\
\hline Czech Republic 1998 & $\overline{15.8}$ \\
\hline Bulgaria 1991 & 18.5 \\
\hline Slovenia 2000 & $\overline{18.8}$ \\
\hline Bulgaria 1994 & $\overline{19.1}$ \\
\hline Slovakia 1998 & 20.2 \\
\hline Czech Republic 1992 & 20.4 \\
\hline Poland 1997 & 21.1 \\
\hline Estonia 1995 & 21.3 \\
\hline Slovakia 1992 & 21.4 \\
\hline Hungary 1994 & 23.7 \\
\hline Slovenia 1996 & 23.8 \\
\hline $\begin{array}{ll}\text { Estonia } & 1999 \\
\end{array}$ & 24.1 \\
\hline Bulgaria 1997 & 24.6 \\
\hline Czech Republic 1996 & 27.0 \\
\hline Romania 2000 & 29.1 \\
\hline Romania 1992 & 30.2 \\
\hline Slovenia 1992 & 30.5 \\
\hline Poland 1993 & 31.7 \\
\hline Hungary 1998 & 32.7 \\
\hline Lithuania 1996 & 35.9 \\
\hline Latvia 1995 & 36.6 \\
\hline Latvia 1998 & 45.2 \\
\hline Lithuania 2000 & 48.5 \\
\hline Mean & 25.9 \\
\hline Standard deviation & 8.92 \\
\hline
\end{tabular}

Source: Author's database based on the data from Rose et al 1998 and internet homepage of Center for the Study of Public Policy (www.cspp.strath.ac.uk/catalog7_0.html); results for 2000 elections in Lithuania, Romania and Slovenia are from other sources (http://www.lrs.lt/n/rinkimai/20001008/index_en.html, www.sigov.si/volitve/eng/enindex.htm, http://www.electionworld.org/romania.htm). All internet sources last accessed on 19.03.2003.

Figure 1. Electoral volatility in Eastern Europe: averages by year

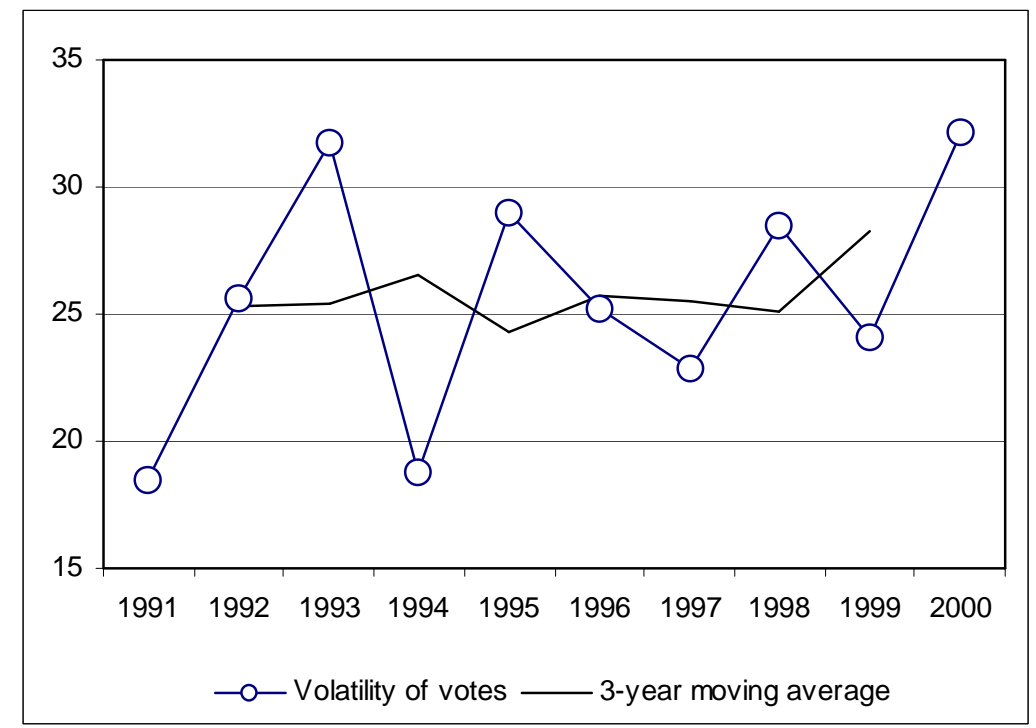


Surprisingly, over time (Figure 1) the volatility levels have not decreased. The three-year moving average has remained around 25 per cent. The same applies to the trend in individual countries. Only Poland and Slovenia have experienced a uniform decrease in volatility and most countries have seen a clear increase in the volatility between the last two pairs of elections, and in some cases (Lithuania, Latvia, Hungary and Romania) it has been considerable.

At the same time, electoral volatility tends to reflect short-term changes in party support rather than long-term dynamics of party systems. While the disparity could be overcome by calculating volatility over more than one electoral period, this is not an easily applicable strategy in the case of East Europe, especially because of frequent splits and mergers. For this reason, only qualitative evaluations can be made whether the volatility has been balancing (i.e. voters swinging to and from the same parties) or cumulative (i.e. parties making successful gains or losses in subsequent elections). Table 2 reveals no uniform pattern in Eastern Europe. About the same number of electoral intervals fall into the balancing and cumulative categories. Some cases fall between these two categories, when some parties do gain or lose progressively, while the support of others swings to and fro. As there have been only few elections in these countries, conclusions remain tentative, but at the same time some countries have apparently experienced stabilizing balancing volatility.

Table 2. Balancing and Cumulative Volatility in Eastern Europe

\begin{tabular}{|c|c|c|c|c|c|c|c|c|}
\hline \multicolumn{2}{|c|}{$\begin{array}{l}\text { Balancing } \\
\text { elections }\end{array}$} & Rather balancing & \multicolumn{2}{|c|}{ Mixed } & \multicolumn{2}{|c|}{ Rather cumulative } & \multicolumn{2}{|c|}{$\begin{array}{c}\text { Cumulative } \\
\text { elections }\end{array}$} \\
\hline \multirow{6}{*}{$\begin{array}{l}\text { Bulgaria } \\
1994 \\
\text { Slovenia } \\
1996 \\
\text { Slovenia } \\
2000\end{array}$} & 1990- & $\begin{array}{l}\text { Bulgaria 1991- } \\
1997\end{array}$ & $\begin{array}{l}\text { Lithuania } \\
2000\end{array}$ & 1992- & $\begin{array}{l}\text { Czech Rep } \\
1996\end{array}$ & 1990- & $\begin{array}{l}\text { Romania } \\
1996\end{array}$ & 1990- \\
\hline & 1990- & Estonia 1992-1999 & Latvia 19 & 1998 & Czech Rep & 1992- & Slovakia & 1990- \\
\hline & & & Romania & 1992- & 1998 & & 1994 & \\
\hline & 1992- & & 2000 & & Hungary & 1990- & & \\
\hline & & & Poland 19 & 1997 & 1998 & & & \\
\hline & & & $\begin{array}{l}\text { Slovakia } \\
1998\end{array}$ & 1992- & & & & \\
\hline
\end{tabular}

Source: Author's assessments. 


\section{GENUINELY NEW PARTIES}

Indices of volatility do not distinguish between the changes that stem from the dynamics between the previously active parties and the impact of newcomers. Given that the party systems in Eastern Europe may look somewhat akin to what has been called the cartel-party system in the Western democracies, evaluation of stability should include an analysis of persistence of incumbent parties versus the success of new parties. The high levels of volatility reported in the previous section can be caused either by strong inner dynamics of a party system or by the powerful entry of new players.

There is considerable body of general literature (i.e., not focused on one country or specific type of parties) on the new parties in Western Europe (Hauss \& Rayside 1978; Harmel \& Robertson 1985; Pedersen 1982, more recently Lucardie 2000; Hug 2000; Mair 2002). Attempts to study the topic in Eastern Europe (Krupavičius 1999: 17-18; Kreuzer \& Pettai 2001) face difficulties because of the short time-span that is available. However, the definition of a 'new party' in these studies differs usually notably from the approach used below. This is primarily owing to the fact that when addressing the new parties in Eastern Europe one must keep in mind that not all the parties that seem new are. The names of existing parties have changed, or the new parties might have been successors of two or more parties that have merged or formed a temporary coalition, or the result of a split of a party or an electoral coalition. A technically new party might be formed by an (sometimes non-party) ex-prime minister or several cabinet ministers or a number of members of parliament, or all these combined. Such parties originate from the already established political circles, thus contributing to inner changes but not altering much the conventional pattern of party politics. In other words, they do not break the party cartel circle.

In this respect, such parties cannot be called genuinely new. Genuinely new parties can be defined as parties that are not successors of any previous parliamentary parties, have a novel name as well as structure, and do not have 
any important figures from past democratic politics among its major members. The last condition excludes participation by prime ministers and significant portions of cabinet ministers and members of parliament. Communist era power holders can form genuinely new parties, except those who entered democratic politics in the founding elections phase in direct continuation of Communist parties. Most of the later entrants anyhow represent rather marginal reincarnations of communist politics and cannot be considered part of the existing party cartel. Several parties in Eastern Europe that have re-entered the parliament after spending one electoral cycle outside will not be considered as genuinely new. However, parties missing from more than one parliament will be regarded as new.

Support for genuinely new parties sheds light on one particular aspect of stability and is insensitive to others. None the less, the measure can still point out some important propensities of party systems. For instance, if few new parties coincide with high aggregate volatility, it indicates changes in the pattern of parliamentary parties, but no significant new actors. This would be different from the situation where the volatility is caused mainly by support for new actors. If new entrants are few over a long period it reduces the incentives of future new groupings to enter the electoral scene and also the incentives of voters to vote for them. This means that political competition is becoming a closed game of incumbents, and the voters' real options are reduced to supporting some of them or exit (i.e., nonvoting).

Table 3 lists the high-volatility elections in Western Europe as indicated by Bartolini \& Mair (1990: 70) with their volatility indices and shares of votes and seats going to genuinely new parties. It is apparent that the volatility scores comparable to the usual volatility levels in Eastern Europe are often accompanied by significant share of votes going to genuinely new parties. 
Table 3. High-volatility elections (over 17\%) in Western Europe

\begin{tabular}{|c|c|c|c|c|}
\hline & & Volatility & $\begin{array}{r}\text { Genuinely new } \\
\text { parties (votes\%) }\end{array}$ & $\begin{array}{l}\text { Genuinely new } \\
\text { parties (seats\%) }\end{array}$ \\
\hline Belgium & 1936 & 17.7 & 11.5 & 10.4 \\
\hline Denmark & 1945 & 18.4 & .0 & .0 \\
\hline Denmark & 1973 & 21.2 & 27.9 & 26.3 \\
\hline Denmark & 1975 & 17.8 & 2.1 & 2.3 \\
\hline Denmark & 1977 & 18.3 & .9 & .0 \\
\hline France & 1906 & 31.1 & .0 & $\overline{.0}$ \\
\hline France & 1910 & 30.5 & 18.2 & 20.1 \\
\hline France & 1924 & 18.7 & 1.0 & .0 \\
\hline France & 1951 & 20.0 & .6 & .6 \\
\hline France & 1956 & 20.2 & 13.4 & 9.9 \\
\hline France & 1958 & 26.7 & 2.8 & .0 \\
\hline France & 1962 & 19.2 & 2.6 & .4 \\
\hline Germany & 1953 & 21.2 & 7.4 & 5.5 \\
\hline Germany & 1920 & 32.1 & .9 & .0 \\
\hline Germany & 1924 & 27.1 & 12.2 & 10.4 \\
\hline Ireland & 1927 & 20.8 & 1.1 & .7 \\
\hline Ireland & 1943 & 20.6 & 10.3 & 9.4 \\
\hline Italy & 1948 & 23.0 & 2.9 & 1.5 \\
\hline Switzerland & 1917 & 22.8 & .0 & .0 \\
\hline Switzerland & 1919 & 23.4 & 18.8 & 17.5 \\
\hline UK & 1931 & 19.2 & 2.0 & 2.1 \\
\hline
\end{tabular}

Source: Aggregate volatility from Bartolini \& Mair (1991), vote shares of genuinely new parties calculated by author after Mackie \& Rose (1991).

The vote shares of genuinely new parties on elections in post-communist countries are given in Table 4. [4] Variation in the scores is considerable. The same countries that had considerably high levels of volatility (Lithuania and Latvia) have higher than average support for genuinely new parties in both of their elections (with respective means 42.2 and 40.9 per cent). At the same time, two countries with lowest average support for genuinely new parties here Poland with the two lowest scores (average 4.0 per cent) and Hungary (average 7.2 per cent) - are around the East European average in volatility. The countries with the two lowest levels of mean electoral volatility (Slovakia and Bulgaria) are in the middle group concerning the support for genuinely new parties (respective means 9.6 and 10.0 per cent). Thus the association between the two indicators is clearly far from perfect as in some countries the volatility has been relatively high despite fairly weak support for genuinely new parties while, on the other hand, there might be only modest volatility accompanied by strong support for genuinely new parties. [5] 
Table 4. Genuinely new parties in Eastern Europe

\begin{tabular}{|c|c|c|c|}
\hline & Volatility & $\begin{array}{r}\text { Genuinely new } \\
\text { parties (votes \%) }\end{array}$ & $\begin{array}{r}\text { Genuinely new } \\
\text { parties (seats\%) } \\
\end{array}$ \\
\hline Poland 1993 & 30.0 & 3.8 & .0 \\
\hline Poland 1997 & 19.3 & 4.2 & .0 \\
\hline Slovenia 1996 & 23.8 & 4.8 & .0 \\
\hline Bulgaria 1997 & 24.6 & 4.9 & .0 \\
\hline Estonia 1999 & 21.0 & 5.5 & .0 \\
\hline Czech Republic 1998 & 15.6 & 5.9 & .0 \\
\hline Slovenia 2000 & 24.6 & 6.1 & 4.4 \\
\hline Hungary 1998 & 32.7 & 6.3 & .3 \\
\hline Czech Republic 1996 & 27.3 & 6.8 & .0 \\
\hline Slovakia 1994 & 13.6 & 7.2 & .0 \\
\hline Hungary 1994 & 23.7 & 8.1 & .3 \\
\hline Slovakia 1992 & 21.4 & 9.0 & .0 \\
\hline Romania 2000 & 29.8 & 9.3 & .0 \\
\hline Bulgaria 1991 & 18.5 & 11.5 & .0 \\
\hline Estonia 1995 & 21.4 & 11.7 & 5.9 \\
\hline Slovakia 1998 & 20.2 & 12.5 & 8.7 \\
\hline Bulgaria 1994 & 19.1 & 13.7 & 5.4 \\
\hline Romania 1992 & 34.0 & 14.5 & 8.5 \\
\hline Romania 1996 & 15.1 & 14.8 & .0 \\
\hline Latvia 1995 & 36.6 & 16.4 & 8.0 \\
\hline Lithuania 1996 & 35.9 & 18.7 & 2.1 \\
\hline Slovenia 1992 & 30.5 & 20.6 & 13.3 \\
\hline Latvia 1998 & 45.2 & 22.8 & 22.0 \\
\hline Lithuania 2000 & 48.5 & 22.9 & 22.0 \\
\hline Czech Republic 1992 & 20.4 & 29.8 & 23.0 \\
\hline Mean & 26.1 & 11.7 & 5.0 \\
\hline Std. Deviation & 8.95 & 6.96 & 7.53 \\
\hline
\end{tabular}

Source: Volatility from Table 1, vote and seat shares of genuinely new parties calculated by author.

As indicated before, there has been no apparent decrease in the East European volatility levels. Yet, there seems to be a modest overall decrease in the popularity of new parties (see Figure 2). The most recent increase is much influenced by the rising vote shares of genuinely new parties in the last elections in Latvia, Lithuania and Slovakia. In individual countries, the trend for new parties between the first and the last elections is overwhelmingly downwards, while volatility clearly is not down. This is in part so because some of the new parties at first win only a few seats and then receive even more support, thus contributing to the volatility reading. Duverger's psychological effect might work on the voters, who vote for more likely successful intra-parliamentary parties than for real newcomers. 
Figure 2. Votes for genuinely new parties in Eastern Europe: averages by year

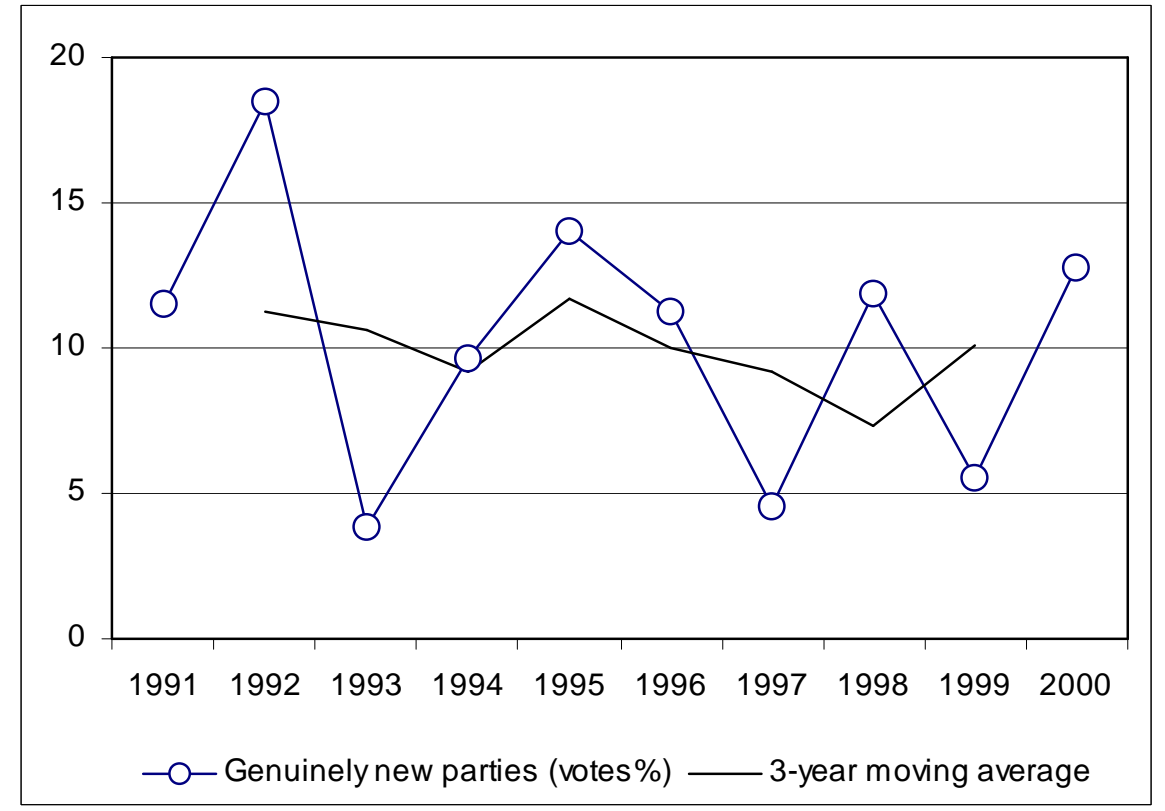

While the extra-parliamentary parties have often received considerable support from the voters, they have in general not been very successful in gaining representation. Out of the 25 elections analysed here, in 12 no new parties won any seats, two Hungarian elections coming very close to that as well [6] (see Table 4). There have been only four elections where the results have been noticeably brighter for new parties (received 10 per cent or more of the seats), among them two (Latvia 1998 and Lithuania 2000) of a recent date. Again, the two southernmost Baltic countries stand out as the countries where the extraparliamentary parties have been successful not only in gaining voters' support, but also gaining seats in the parliaments (with on average 15.0 per cent Latvian and 12.1 per cent Lithuanian seats filled with representatives of genuinely new parties). On the other hand, in Poland no genuinely new party has ever entered the Sejm, while the average is also low for Hungary, and Bulgaria (respective means 0.3 and 1.8 per cent).

The tendencies apparent in the vote shares of genuinely new parties over time are more manifest in their seat shares. Following initial successes after the first electoral cycle there was a compelling downturn in most countries in the mid1990s (see Figure 3). There have been some success stories lately (e.g., last 
elections in Latvia, Lithuania and Slovakia) - so that the overall three-year moving average of the seat shares is highest at the end of the time period under consideration. However, in all but the abovementioned three countries, the number of seats gained by genuinely new parties has dropped from the first elections to the last.

Figure 3. Volatility and genuinely new parties in Eastern Europe and in high-volatility elections in Western Europe.

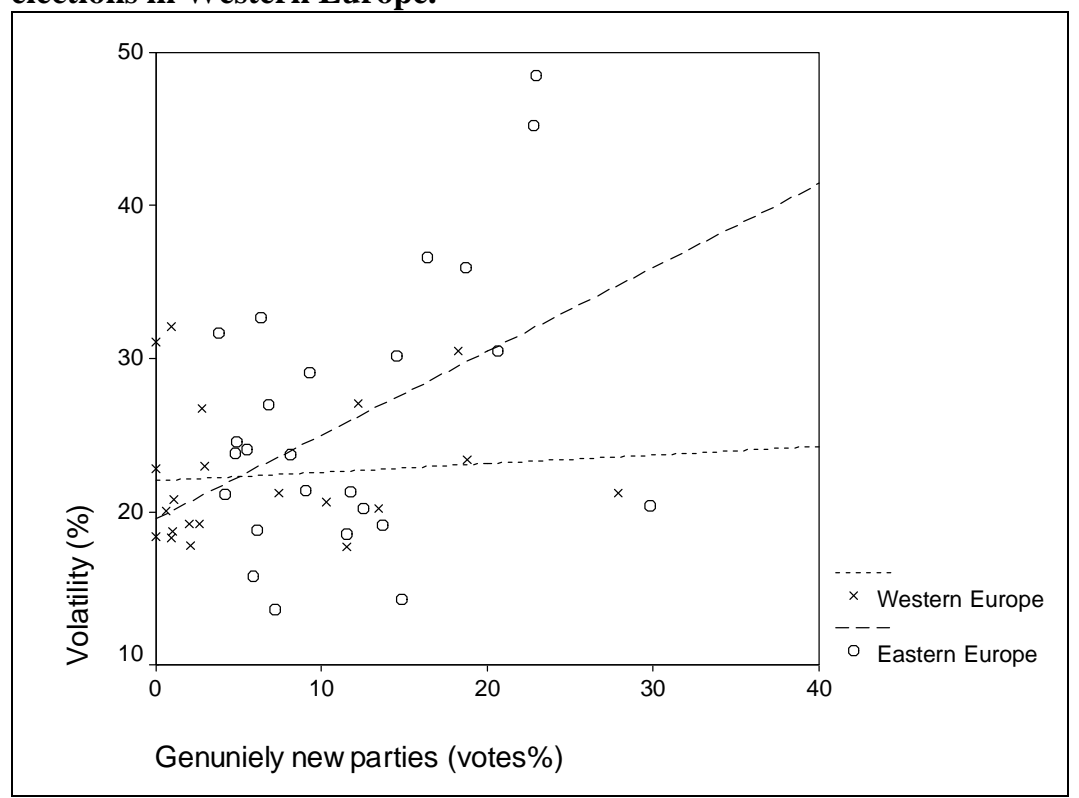

Equations for best-fit lines:

Western Europe: volatility $=22.015+0.056 *$ genuinely new parties $(\mathrm{v} \%) \mathrm{R}^{2}=0.0096$

Eastern Europe: volatility $=19.536+0.547 *$ genuinely new parties $(\mathrm{v} \%) \mathrm{R}^{2}=0.1826$ 


\section{COMPARING VOLATILITY AND THE PERFORMANCE OF GENUINELY NEW PARTIES}

Comparison of volatility and support for genuinely new parties in Eastern Europe vis-à-vis West European high-volatility elections reveals a slightly positive relationship in Eastern Europe, while in West European high-volatility elections the relationship between volatility and vote shares of genuinely new parties has been ambiguous (see Figure 4). Even though the correlation is significant in Eastern Europe, less than a fifth of variation in volatility can be explained by the popularity of newcomers.

Figure 4. Seats (\%) for genuinely new parties in Eastern Europe: averages by year

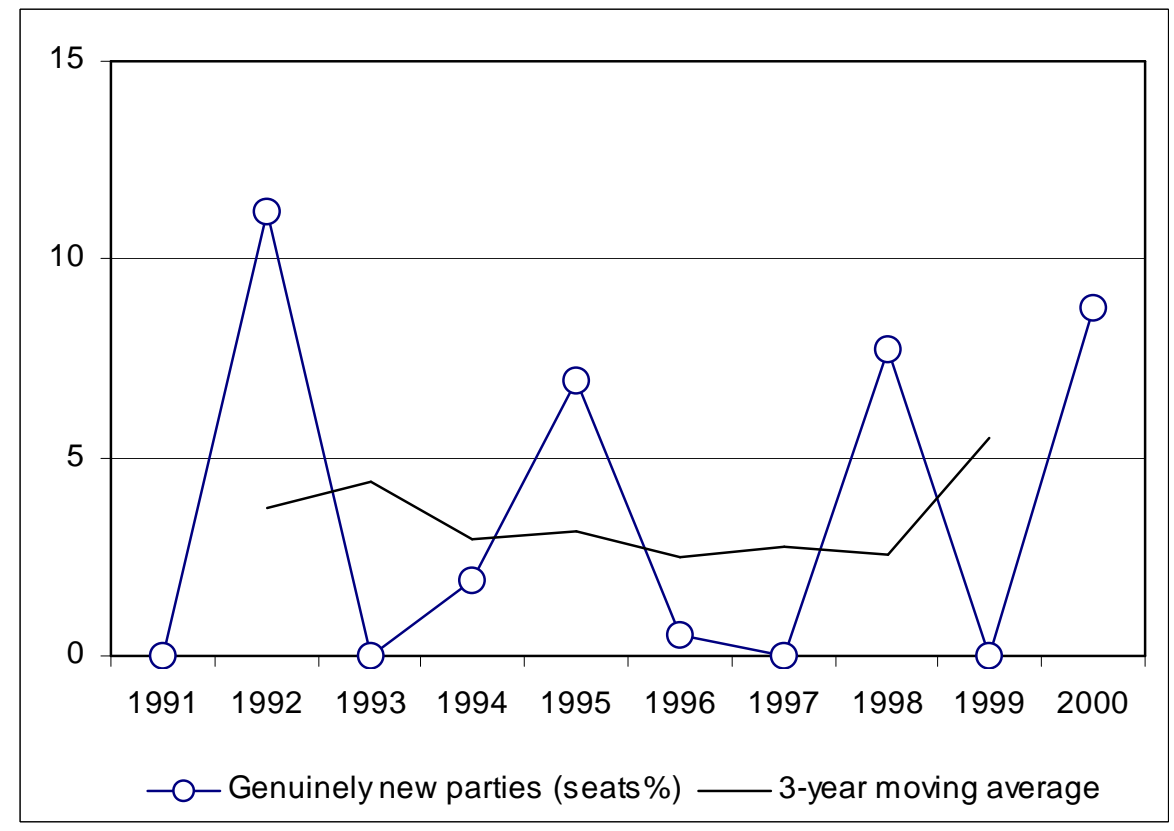

While support for parties in elections is relevant for analysing the changes in party systems, the subsequent changes in the composition of parliaments are at least as important. Figure 5 displays the relationship of the votes and seats shares of genuinely new parties in the two groups of countries. Here, the difference between the post-communist and traditional democracies is obvious. In the West the genuinely new parties gain representation much more easily than in the East. 
Even though the tendency is apparent all over the figure, the lower part is especially intriguing. In the high-volatility elections in Western Europe the highest percentage of votes received by genuinely new parties winning no seats has been 2.8 per cent (France in 1958). In the post-communist elections, in contrast, there have been only three cases where the genuinely new parties have secured seats while receiving less than ten per cent of votes (in 2000 in Slovenia, and in two marginal cases in Hungary where they won one seat). As already noted above, in almost half of the elections they have failed to gain any representation these include two cases where the genuinely new parties were supported by more than 10 per cent of the voters (11.5 per cent in Bulgaria 1991 and as many as 17.7 per cent in Romania 1996). On the other hand, out of the thirteen elections in Western Europe where the genuinely new parties received less than 10 per cent of the votes, in more than half of them (seven) they succeeded in securing representation. The more favourable situation for new parties in Western Europe is apparent on all levels of their electoral support.

Figure 5. Genuinely new parties: seats and votes in Eastern and Western

\section{Europe.}

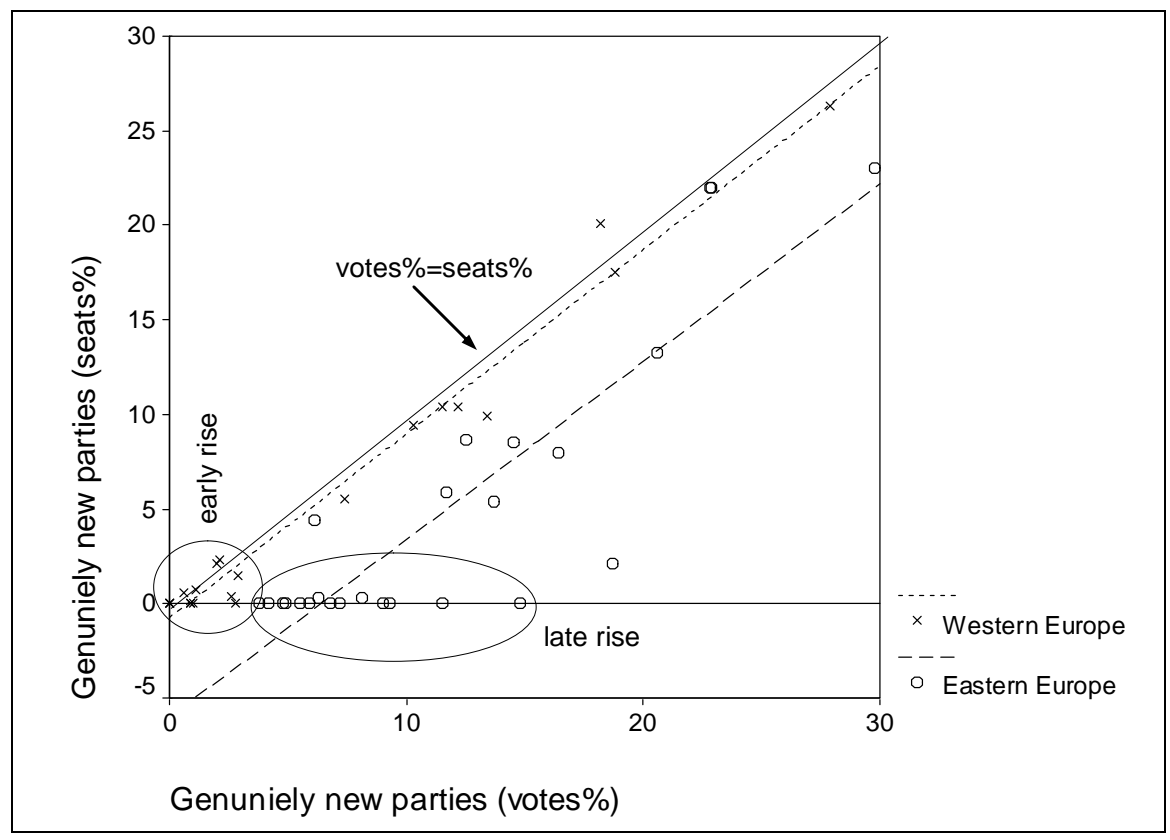

Equations for best-fit lines:

Western Europe: Seats $\%=-0.757+0.974 *$ Votes $\% . \mathrm{R}^{2}=0.977$

Eastern Europe: Seats\% $=-6.026+0.941 *$ Votes $\% . \mathrm{R}^{2}=0.758$ 
The reason for this difference is most likely the highly unfavourable electoral laws for the smaller parties in general (especially high legal thresholds compared to traditional democracies [7]) and only secondarily the dispersion of votes between several genuinely new parties. If Figure 5 presented vote and seat shares of individual genuinely new parties, the picture would be similar showing early rise in gaining representation in Western Europe and late rise in Eastern Europe at relatively low levels of support (almost up to 5 per cent of popular vote) parties have been better able to gain representation in the former. At higher levels of support the genuinely new parties have been roughly equal in gaining representation, the Eastern parties being perhaps slightly more successful than their Western counterparts. Thus the electoral laws in effect have blocked the success of genuinely new contenders for power. Simultaneously they have often received considerable support from the voters - probably due to the slow working of Duverger's psychological effect that should limit the voter readiness to support the parties that fail to secure representation in the parliament. At the same time the occurrence of psychological effect is doubtful in cases where the parties participate only for the first time in elections. Given the relatively volatile nature of electoral politics, the psychological effect might be overshadowed by some kind of gambling-like approach to voting.

\section{SUBSEQUENT PERFORMANCE OF SUCCESSFUL GENUINELY NEW PARTIES}

What happens to the lucky genuinely new parties after initial success? Table 5 lists these parties and their performance in subsequent elections after their entry to the parliament. Only these cases can be analysed in which the parties entered the parliament before the most recent elections - and this leaves us with thirteen cases. Four of these parties disappeared from the parliament after the next elections, the fifth after two elections. Of the remaining eight, three have become highly successful, becoming one of the major parties. These are the Czech Social Democratic Party, Greater Romanian Party, and the Lithuanian Liberal Union. The latter's success is due to later co-optation of resigned Prime Minister 
Rolandas Paksas, while they were only a marginal parliamentary party before. The two other parties are genuine success stories.

Of the five parties that neither disappeared from the parliamentary scene nor became major parties, two clearly lost support (National Party Young Lithuania and Slovenian National Party). Bulgarian Business Bloc and Our Home is Estonia/Estonian United People's Party retained their popularity, [8] and Lithuanian Peasants' Party somewhat increased it.

As eight of the new parties cannot be considered because they have not yet contested any national elections after their initial success, conclusions are preliminary. Still, it seems that most of the genuinely new parties that succeeded in entering the parliament fail afterwards or at least do not increase their support much. Ten countries and twenty-five elections under analysis offer only two genuine success stories so far. Some further parties - especially Latvian Social Democratic Alliance, Lithuanian New Union and Slovak Party of Civic Understanding - may have the potential for not only entering but also remaining in the political scene. 
Table 5. Subsequent performance of successful genuinely new parties

\begin{tabular}{|c|c|c|c|c|c|c|c|}
\hline \multirow{3}{*}{$\begin{array}{l}\text { Country/year } \\
\text { Bulgaria } 94\end{array}$} & \multirow[b]{2}{*}{ Party } & \multicolumn{2}{|c|}{$\begin{array}{l}\text { Elections } \\
\text { of entry }\end{array}$} & \multicolumn{2}{|c|}{ Second elections } & \multicolumn{2}{|c|}{ Third elections } \\
\hline & & \multicolumn{6}{|c|}{ votes $\%$ seats $\%$ votes $\%$ seats $\%$ votes $\%$ seats $\%$} \\
\hline & Bulgarian Business Bloc & 4.7 & 5.4 & 5.0 & 5.0 & NY & NY \\
\hline Czech Rep 92 & Czech Social Democratic Party & 6.5 & 8.0 & 26.4 & 30.5 & 32.3 & 37.0 \\
\hline Czech Rep 92 & Liberal Social Union & 6.5 & 8.0 & - & $-* * *$ & - & - \\
\hline Czech Rep 92 & Association for the Republic & 6.0 & 7.0 & 8.0 & 9.0 & 3.9 & 0.0 \\
\hline Slovakia 98 & Party of Civic Understanding & 8.0 & 8.0 & NY & NY & NY & NY \\
\hline Estonia 95 & $\begin{array}{l}\text { Our Home is Estonia/United } \\
\text { People's Party }\end{array}$ & 5.9 & 5.9 & 6.1 & 5.9 & NY & $\mathrm{NY}$ \\
\hline Latvia 95 & Latvian Unity Party & 7.2 & 8.0 & 0.5 & 0.0 & NY & $\overline{N Y}$ \\
\hline Latvia 98 & $\begin{array}{l}\text { Social Democratic Alliance } \\
\text { (prev. Labour \& Justice) }\end{array}$ & 12.8 & 14.0 & NY & NY & NY & NY \\
\hline Latvia 98 & New Party & 7.3 & 8.0 & NY & NY & NY & $\mathrm{NY}$ \\
\hline Lithuania 96 & $\begin{array}{lll}\text { National } & \text { Party } & \text { Young } \\
\text { Lithuania* } & & \\
\end{array}$ & 4.0 & 0.7 & 1.2 & 0.7 & NY & NY \\
\hline Lithuania 96 & Liberal Union* & 1.9 & 0.7 & 17.3 & 24.1 & NY & $\mathrm{NY}$ \\
\hline Lithuania 96 & Peasant's Party* & 1.7 & 0.7 & 4.1 & 2.8 & NY & $\overline{N Y}$ \\
\hline Lithuania 00 & Liberty (Freedom) Union* & 1.3 & 0.7 & NY & NY & NY & $\mathrm{NY}$ \\
\hline Lithuania 00 & New Union (Social Liberals) & 19.6 & 20.6 & NY & NY & NY & NY \\
\hline Lithuania 00 & $\begin{array}{l}\text { People's Union "For the Fair } \\
\text { Lithuania"* }\end{array}$ & 1.5 & 0.7 & NY & NY & NY & NY \\
\hline Hungary 94 & Liberal Bourgeoisie Alliance* & 0.6 & 0.3 & 0.1 & 0.0 & NY & $\overline{N Y}$ \\
\hline Hungary 98 & Independent* & $\mathrm{NA}^{* *}$ & 0.3 & NY & NY & NY & $\overline{N Y}$ \\
\hline Romania 92 & Greater Romania Party & 3.9 & 4.7 & 4.5 & 5.6 & 19.5 & 24.3 \\
\hline Romania 92 & Socialist Labour Party & 3.0 & 3.8 & 2.1 & 0.0 & NY & NY \\
\hline Slovenia 92 & Slovenian National Party & 10.0 & 13.3 & 3.2 & 4.4 & 4.4 & 4.4 \\
\hline Slovenia 00 & Slovenian Youth Party & 4.3 & 4.4 & NY & NY & NY & $\mathrm{NY}$ \\
\hline $\begin{array}{l}\text { * - entered fro } \\
* * \text { - contested } \\
* * *-\text { split up a } \\
\text { NY - not yet a } \\
\text { Source: see Ta }\end{array}$ & $\begin{array}{l}\text { on the one-mandate districts } \\
\text { and successors vanished } \\
\text { applicable } \\
\text { able } 1 .\end{array}$ & & & & & & \\
\hline
\end{tabular}

Another measure of the parties' performance is whether they have succeeded in entering the government. Out of all the twenty-one parties listed in Table 5, seven have done so. The Czech Social Democrats and Lithuanian Liberal Union have acquired a major role by receiving the prime ministerial post (Milos Zeman and Rolandas Paksas, respectively). The other parties that have obtained cabinet positions at different times are the Slovak Party of Civic Understanding, Latvian Unity Party and New Party, Lithuanian New Union (Social Liberals) and Latvian Social Democratic Alliance. The success on the executive level has been relatively modest. This has happened in only four of the ten countries. 


\section{CONCLUSION}

The party systems in the young democracies of Eastern Europe are more dynamic than their counterparts in Western Europe in several respects. Electoral volatility has been high - comparable at best with the elections with the very highest volatility in traditional democracies, but often even much higher. This also confirms that volatility has not uniformly declined in the post-communist countries, and has even clearly increased in some of them. Yet, the index of volatility is blind to the parties involved in contributing to it. Given the possibility of cartelisation of Eastern European party systems, this study has analysed an additional aspect - the possibilities and performance of parties that are completely new to the particular political system. Given the frequent occurrence of splits, mergers, coalitions and renamings of the already incumbent parties, distinction has been carefully made between the parties that are actually continuations of old parties and parties that are genuinely new to the system.

Such parties have not generally been successful in East European countries. In one half of the elections they have received less than ten per cent of the popular vote and in most countries their share of votes has decreased over time. While the median support around ten percent might be still considered relatively high, these parties have been much less successful in gaining and retaining representation in the parliament. In one half of the elections they gained no seats or only a minuscule representation. Unfavourable electoral rules and the diffusion of support among too many genuinely new parties have made it more difficult for them to gain representation in the East European parliaments than has been the case in West European high-volatility elections. The subsequent performance of the initially successful genuinely new parties has been mixed. Only two of them have become major players in their respective party systems, a third one becoming so after later incorporation of a former prime minister. In most countries the party system persistence has been surprisingly high - in more than half of the cases the parties that made up the first democratic parliament and the 
parties making up the legislatures today overlap heavily (by more than 85 per cent).

In sum, while volatility has been very high in most East European elections, successful entrance of truly new players has been surprisingly limited and the two measures correlate poorly. While the average level of volatility has not decreased during the decade, the level of support for genuinely new parties has declined in most cases. The apparent variation in all of the measures across countries signals the need to consider possible cross-country differences in future studies.

A final comment on the evaluation of the findings should be made. The words 'stability' and 'instability' have clearly positive and negative connotations. This may to lead to the conclusion that countries with higher levels of party system stability are better off regarding development of democracy. While too much change over extended time periods is undoubtedly adverse for democracy, too much stability can lead to inertia and stagnation. One has to keep in mind that we are dealing with democratic development in the post-communist countries, where some development (i.e., dynamics) in the party systems could be even necessary. Indeed, the values held by parties (and their leaders) in the embryonic phase of democracy can easily be a hindrance rather than advantage for subsequent democratic development.

In many of the post-communist countries that can claim relatively stable party systems this has been achieved partly because of the low degree of success of genuinely new parties. While this indeed is an important sign of stability, one has to be careful with praising it too high. Often this has been achieved not through the new parties' low appeal to the electorate but by hindrances to their success (electoral rules, public funding of parliamentary parties, etc). When this is accompanied by dissatisfaction with the existing parties and declining turnout in elections, it is doubtful whether one can talk about stability that furthers democratic development. Instead, it can be unhealthy closedness of the political scene where the only real option for the dissatisfied voters is exit from the 
electoral game because there are no promising new contenders or their chances for success are too low.

\section{NOTES}

1. Aggregate volatility is the sum of absolute values of vote percentage changes of parties from an election to another divided by two (Pedersen 1979: 4).

2. For the purposes of this article party is defined as an organization that participates in an election under a distinctive name - a definition that resembles that of Sjöblom (1968). It could be interpreted as a party that has passed the threshold of authorization (Pedersen 1982: 7). No distinction is made between parties and electoral coalitions. Such distinction is often difficult because it depends appreciably on the particular country's party and electoral regulations. In some cases it might be beneficial for parties to run alone, while in others it is more practical to join coalitions. Sometimes coalitions are barred altogether, even if parties might prefer to form them. The parties that have run together have merged afterwards in some cases while in others the electoral coalitions have been fairly loose associations. Although having shortcomings, defining party as an electoral entity is both the easiest and the most clear-cut option.

3. Yet, sometimes the indices have not been calculated quite adequately, most likely for failing to take into account the development patterns of the party systems For instance, Rose et al. (1999: 119) report that the lowest volatility index in Eastern Europe in the last decade is for the 1992 Romanian elections 4.5 per cent. Comparing the results of 1990 and 1992 elections shows that the volatility score should be significantly higher, in fact among the highest in postcommunist countries. The possible reason is misreading of the evolutional paths of individual parties. Bartolini \& Mair (1990: 311) consider splits those separations deriving from official decisions of a minority within the structure of a given party. However, the party structures during the time period of the study have been weak and vague in the post-communist countries, which makes the 
application of the above rule practically impossible. Thus, each electoral unit that has among its principal members people that were in prominent positions (i.e. received a seat in parliament) in a former party's lists, is considered to constitute a split. The volatility scores used in this article are available from the author on request.

4. Full list of genuinely new parties is available on request from the author.

5. The highest percentage of votes cast for genuinely new parties (at the 1992 elections in the Czech Republic) was accompanied by rather low volatility chiefly because most of the genuinely new parties participated with fairly strong support (yet no success in winning seats) already in 1990.

6. Genuinely new parties gained seats only in single mandate constituencies there.

7. In the Western European countries under consideration here, the legal thresholds are either not present, are lower, or the electoral system is not PR. Contrary to some preconceived notions, single member districts offer lower thresholds of inclusion than PR districts (Taagepera 1998).

8. In 'Our Home is Estonia' Estonian United People's Party ran together with two other ethnic Russian parties in 1995. Its 1999 coalition with Social Democratic Labour Party is considered its successor.

\section{REFERENCES}

Ágh, A. (1998). The Politics of Central Europe. London: Sage.

Bartolini, S. \& Mair P. (1990). Identity, competition and electoral availability: the stabilisation of European electorates 1885-1985. Cambridge: Cambridge University Press. 
Chan, K. K.-L. (2001). Structuralism versus intentionalism in Post-communist Party System Evolution, Party Politics 7(5): 605-619.

Crewe, I. \& Denver, D., eds. (1985). Electoral Change in Western Democracies: Patterns and Sources of Electoral Volatility. New York, NY: St.Martin's Press.

Day, A.J., German, R. \& Campbell, J., eds. (1996). Political parties of the world. London: Cartermill.

Ersson, S. \& Lane, J.E. (1998). Electoral instability and party system change in Western Europe, in P. Pennings \& J.E. Lane (eds.), Comparing Party System Change. New York: Routledge, (pp. 23-39).

Harmel R. \& Robertson, J. (1985). The Formation and Success of New Parties, International Political Science Review 6(4): 501-523.

Hauss, C. \& Rayside, D. (1978). The Development of New Parties in Western Democracies since 1945, in L. Maisel \& J. Cooper (eds.), Political Parties: Development and Decay. Beverly Hills, CA: Sage, (pp. 31-57).

Hug, S. (2000). Studying the Electoral Success of New Political Parties, Party Politics 6(2): 187-197.

Katz, R.S. \& Mair, P. (1995). Changing Models of Party Organization and Party Democracy: The Emergence of the Cartel Party, Party Politics 1(1): 5-28.

Klíma, M. (1998). Consolidation and Stabilization of the Party System in the Czech Republic, in R. Hofferbert (ed.), Parties and Democracy. Oxford: Blackwell, (pp. 70-88).

Korasteleva, E.A. (2000). Electoral Volatility in Postcommunist Belarus: Explaining the Paradox, Party Politics 6(3): 343-358. 
Krupavičius, A. (1999). Party Systems in Central East Europe: Dimensions of System Stability. Glasgow: University of Strathclyde, Studies in Public Policy.

Lewis, P.G. (1998). Party Funding in Post-Communist East-Central Europe, in P. Burnell \& A. Ware (eds.), Funding Democratization. Manchester: Manchester University Press, (pp. 137-157).

Lucardie, P. (2000). Prophets, Purifiers and Prolocutors, Party Politics 6(2): 175185.

Mackie, T. \& Rose, R. (1991). The International Almanac of Electoral History. $3^{\text {rd }}$ Edition. London: Macmillan.

Mair, P. (1999). New Political Parties in Established Party Systems: How Successful Are They? in E. Beukel, K. K. Klausen \& P. E. Mouritzen (eds.), Elites, Parties and Democracy: Festschrift for Professor Mogens N. Pedersen. Odense University Press, (pp. 207-221).

Mair, P. (2002). In the aggregate: Mass electoral behaviour in Western Europe, in H. Keman (ed.), Comparative Democratic Politics. London: Sage.

Mainwaring, S. (1998). Party Systems in the Third Wave, Journal of Democracy 9(3): 67-81.

Olson, D. (1993). Political Parties and Party Systems in Regime Transformation: Inner Transition in the New Democracies of Central Europe, The American Review of Politics 14(1): 619-658.

Pedersen, M.N. (1979). The Dynamics of European Party Systems: Changing Patterns of Electoral Volatility, European Journal of Political Research 7(1): 126. 
Pedersen, M.N. (1982). Towards a New Typology of Party Lifespans and Minor Parties, Scandinavian Political Studies 5(1): 1-16.

Kreutzer, M. \& Pettai, V. (2001). Formation of Party Systems in Post-Communist Democracies: Comparing Estonia, Latvia and Lithuania, paper presented at the Annual Meeting of the American Political Science Association, August 31 September 3, 2001.

Rattinger, H. (1997). Nomination: To Swing or not to Swing, European Journal of Political Research 31(1): 86-93.

Rose, R., Munro, N. \& Mackie, T. (1998). Elections in Central and Eastern Europe Since 1990. University of Strathclyde: Studies in Public Policy.

Sjöblom,G. (1968). Party Strategies in a Multiparty System. Lund: Studentlitteratur.

Szajkowski, B., ed. (1994). Political parties of Eastern Europe, Russia and the successor states. Harlow: Longman.

Szczerbiak, A. (2001) Cartelisation in Post-Communist Politics: State Party Funding in Post-1989 Poland, Perspectives on European Politics and Society 2(3): 431-451.

Taagepera, R. (1998). Nationwide Inclusion and Exclusion Thresholds of Representation, Electoral Studies 17(4): 405-417.

Tóka, G. (1997). Political Parties and Democratic Consolidation in East Central Europe. Glasgow: University of Strathclyde, Studies in Public Policy. 